\title{
Whole powder pattern decomposition methods and applications: A retrospection
}

\author{
Armel Le Bail ${ }^{\text {a) }}$ \\ Laboratoire des Oxydes et Fluorures, CNRS UMR 6010, Université du Maine, avenue O. Messiaen, \\ 72085 Le Mans Cedex 9, France
}

(Received 30 June 2005; accepted 12 October 2005)

\begin{abstract}
Methods extracting fast all the peak intensities from a complete powder diffraction pattern are reviewed. The genesis of the modern whole powder pattern decomposition methods (the so-called Pawley and Le Bail methods) is detailed and their importance and domains of application are decoded from the most cited papers citing them. It is concluded that these methods represented a decisive step toward the possibility to solve more easily, if not routinely, a structure solely from a powder sample. The review enlightens the contributions from the Louër's group during the rising years 1987-1993. (C) 2005 International Centre for Diffraction Data. [DOI: 10.1154/1.2135315]
\end{abstract}

Key words: powder diffraction, whole powder pattern decomposition, intensity extraction, $a b$ initio structure determination

\section{INTRODUCTION}

A modern definition for whole powder pattern decomposition (WPPD) methods would be that they simultaneously have to refine the unit-cell parameters and extract the best estimations of the Bragg peak intensities from a complete diffractogram. This is done very fast nowadays, irrespective of the number of Bragg peaks present in a powder diffraction pattern, but we did not attain this comfortable situation without some past efforts. The WPPD methods' introduction occurred slowly and progressively thanks to the increase in computer power, the improvements in graphical user interfaces, the diffractometer data digitalization, the availability of synchrotron and neutron radiation, and last but not least, the proposition of new algorithms. Innovations were not instantly accepted (this being true for all the whole powder pattern fitting methods including the Rietveld and the decomposition methods) or could not be applied immediately to every radiation source or diffractometer (the hardware) before adaptations made by an essential category of crystallographers being conceivers and developers of the software. Ancestors of the WPPD methods extracted peak intensities without the cell restraint, so that each peak position was a parameter to be refined (as well as the peak intensity, the peak shape and its width). This is still useful if the aim is the search for the peak positions for indexing, though derivative methods can make that peak-position-hunting job faster. Taking advantage of the indexing [see a recent review paper by Bergmann et al. (2004)], new WPPD methods, applying cell restraint to the peak position, opened the door to a long list of new possibilities and applications (including first indexing confirmation) which are detailed in this paper. However, only some selected application references will be provided because the number of papers involved is quite high and increasing (more than 2000 texts specify the use of WPPD methods). Contributions from Rennes by Louër's group from 1987 to 1993 will be especially enlightened, not forgetting the other players during that same time, restraining generally to the structure determinations by powder diffractometry

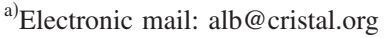

(SDPD) applications published in the early stages of this retrospection (because the subsequent activity increased too considerably, by more than 850 SDPDs in the last ten years). If only a partial review of applications can be given, the evolution of the methods will be discussed as completely as possible.

\section{WPPD VERSUS WPPF}

Whole powder pattern fitting (WPPF) is a general definition including WPPD as well as the Rietveld method (Rietveld, 1969). In the latter method, the atomic coordinates are required for the intensities calculations, and the sum of all the peak contributions produces a calculated powder pattern which is compared to the observed one, allowing the least-squares refinement of profile and structural parameters, altogether. The fact is that the Rietveld method historically preceded the modern WPPD methods though the latter are applicable without atomic coordinates. Of course, one may use WPPD methods also if the structure is known, but for any reason, one does not want to use that knowledge or a part of it (not wanting to restrain the peak intensity by the structural model, for instance, nevertheless believing in the indexing, or wanting to confirm it, thus using the restraint of the cell parameters, etc.). Any WPPF approach should be able to model the peak shape and width changes according to the diffraction angle variations. This can be done by fitting some analytical profile shape and width parameters in a semiempirical approach, the angular variation of these parameters is generally controlled by refining the $U, W$, and $W$ terms in the Caglioti et al. (1958) law $\left[(\mathrm{FWHM})^{2}\right.$ $\left.=U \tan ^{2} \theta+V \tan \theta+W\right]$, possibly modified. The alternative is by using the fundamental parameter approach by raytracing or not (Cheary and Coelho, 1992). However, some ancestor programs did not apply any cell restraint.

\section{WPPD ANCESTORS}

Obtaining all the peak positions, areas, breadths, and shape parameters, as independent parameters, for a whole 
powder pattern is obviously limited to simple cases where there is not too much peak overlap. With such an approach (both cell and space group unknown, or this information known but not used at all) one has to provide the estimation of a number of peaks to be fitted, so that the fit of a complex group of peaks leads to large uncertainties if the cell is unknown. However, knowing the cell and space group and still using the peak position as a refinable parameter provides at least the correct number of peaks and an estimation of their starting position. Such calculations were made as an alternative to the Rietveld method, during the first stage of the so-called two-stage-method for refinement of crystal structures (Cooper et al., 1981). Some controversy and resistance to the use of the Rietveld method continues even nowadays. In the case of X-ray data, the profile shapes applied in the Rietveld method, Gaussian at the origin for neutron data, evolved a lot (Wiles and Young, 1981), and on the WPPD side, happened to be described in these two-stage approaches by a sum of Lorentzian curves (Will et al., 1983), or doubleGaussian (Will et al., 1987). The computer program PROFIT, deriving from a software for individual profile fitting (Sonneveld and Visser, 1975) and extended to the whole pattern, was applied to the study of crystallite size and strain in zinc oxide (Langford et al., 1986) and for the characterization of line broadening in copper oxide (Langford and Louër, 1991). Studying a whole pattern can also be done in simple cases by using software designated for the characterization of single or small groups of peaks, an example is a $\mathrm{ZnO}$ study (Langford et al., 1993) by using the computer program FIT (Socabim/Bruker). However, WPPD on complex cases is mostly realized nowadays by using peak positions controlled by the cell parameters, even if the loss of that freedom degree may lead to slightly worse fits, increasing a bit the profile $R$ factors. Before 1987, close to 30 SDPDs were done from intensities extracted by using these ancestor WPPD methods without cell restraint [see the SDPD database-Le Bail, (2005a)]. Those SDPDs realized in Louër's group by using mainly the computer program PROFIT were either zirconium, cadmium, or rare-earth nitrates (Marinder et al., 1987; Louër and Louër, 1987; Louër et al., 1988; Plevert et al., 1989; Bénard et al., 1991). It can be argued that freeing the peak positions allows for taking account of subtle effects in position displacement (in stressed samples for example). But systematic discrepancy of observed peak positions with regard to the theoretical position, as expected from cell parameters, can be modeled as well in modern WPPD methods or even in the Rietveld method.

\section{CELL-RESTRAINED WPPD}

Obligation made to the WPPD methods to apply strictly the peak positions calculated from a cell (hypothesis from indexing results) marked a great step in the quest for $a b$ initio structure determination by powder diffractometry (SDPD). This is essentially because the quality of the estimated intensities globally increased, and even if the main handicap of powder diffraction (peak overlapping) could not be completely circumvented, it was at least more clearly delimited. Nowadays two generic names are retained for such cell-restrained WPPD methods which can produce a set of extracted intensities suitable for attempting a structure solu- tion: the Pawley and Le Bail methods. Both were derived from the Rietveld method.

\section{A. The Pawley method}

Removing the crystal structure refinement in a Rietveld software, and adding the possibility to refine an individual intensity for every expected Bragg peak produced a new software (named ALLHKL) allowing one to refine the cell parameters very precisely and to extract a set of structure factor amplitudes (Pawley, 1981). The process was much later called the "Pawley method" by some users. Overcoming the least-squares ill-conditioning due to peak overlap was done by using slack constraints. The author clearly insisted on the usefulness of that procedure for the confirmation of the cell indexing of a powder pattern of an unknown. Nevertheless, no SDPD of an unknown was realized by using the Pawley method for several years (although several successful tests were published corresponding to remakes of previously known structures). The first real SDPD of an unknown realized by using the Pawley method seems to be that of $\mathrm{I}_{2} \mathrm{O}_{4}$ (Lehmann et al., 1987) of which the powder pattern had been previously indexed, but the structure not determined due to the lack of suitable single crystal. During these pioneering years, the version of ALLHKL available could not extract the intensities for more than 300 peaks, so that, in case of more complex cases, it was necessary to carve the pattern in several parts. Moreover, it was a bit difficult to avoid completely the ill-conditioning due to overlapping. Being successful provided equipartitioned intensities (i.e., equal structure factors for those $h k l$ Bragg peaks with exact overlap). Being unsuccessful could well produce negative intensities which, combined with positive ones for other peak(s) at the same angle, reproduced the global positive value. Moreover, the first version applying Gaussian peak shapes could not easily produce any SDPD due to the relatively poor resolution of constant wavelength neutron data, so that it needed to be adapted to X-ray data, with the implementation of more complex peak shapes. A series of programs were proposed next, based on the same principles as the original Pawley method (i.e., with cell restraint). The first of them, by Toraya (1986), extended the use to X-ray with non-Gaussian profile shapes, introduced two narrow band matrices instead of a large triangle matrix, saving both computation time and memory space in a program named WPPF. Some programs were used to produce intensities in order to apply the socalled two-stage method (Cooper et al., 1981) for structure refinement, instead of applying the Rietveld method, such as PROFIT (Scott, 1987) and PROFIN (Will, 1988, 1989) (no slack constraints, but equal division of the intensity between expected peaks when the overlap is too close). There was an intense continuing activity on Pawley-type software with other programs named FULFIT (Jansen et al., 1988), LSQPROF (Jansen et al., 1992), and POLISH (Byrom and Lucas, 1993). Improving the estimation of intensities of overlapping reflections in LSQPROF by applying relations between structure factor amplitudes derived from direct methods and the Patterson function was considered in a satellite software DOREES (Jansen et al., 1992). That question about how to determine the intensities of completely (or largely) overlapping reflections (systematic overlap due to symmetry or fortuitous overlap) in powder diffraction patterns cannot have a definite simple 
answer but continues to be discussed a lot since it is essential for improving our ability to solve structures. An early view with a probabilistic approach was given by David (1987), introducing later Bayesian statistics (Sivia and David, 1994) inside of the Pawley method. Early finding of preferred orientation on the basis of analysis of $E$-value distribution was another way (Peschar et al., 1995) to improve the structure factor amplitude estimate.

\section{B. The Le Bail method}

In order to be able to estimate $R$ factors related to integrated intensities, Rietveld (1969) stated [see also the book edited by Young (1993)]: "a fair approximation to the observed integrated intensity can be made by separating the peaks according to the calculated values of the integrated intensities, i.e."

$$
I_{K}(\mathrm{obs})=\sum_{j}\left\{w_{j . K} \cdot S_{K}^{2}(\mathrm{calc}) \cdot y_{j}(\mathrm{obs}) / y_{j}(\mathrm{calc})\right\},
$$

where $w_{j . K}$ is a measure of the contribution of the Bragg peak at position $2 \theta_{K}$ to the diffraction profile $y_{j}$ at position $2 \theta_{j}$. The sum is over all $y_{j}$ (obs) which can theoretically contribute to the integrated intensity $I_{K}(\mathrm{obs})$. So that there is a bias introduced here by the apportioning according to the calculated intensities, this is why the observed intensities are in fact said to be "observed," under quotes, in the Rietveld method. These "observed" intensities are used in the $R_{B}$ and $R_{F}$ calculations (reliabilities on intensities and structure factor amplitudes). They are also required for Fourier map estimations, which, as a consequence, are less efficient than from single crystal data. A process using iteratively the Rietveld decomposition formula for WPPD purposes was first applied in 1988 (Le Bail et al.) and called much later the "Le Bail method" or "Le Bail fit," or "pattern matching" as well as "profile matching" in the FULLPROF Rietveld program (Rodriguez-Carvajal, 1990). In the original computer program (named ARITB) first applying that method, arbitrarily all equal $S_{K}^{2}$ (calc) values are first injected in the above equation, instead of using structure factors calculated from the atomic coordinates, resulting in " $I_{k}(\mathrm{obs})$ " which are then re-injected as new $S_{K}^{2}$ (calc) values at the next iteration, while the usual profile and cell parameters (but not the scale) are refined by leastsquares (ARITB used profile shapes represented by Fourier series, either analytical or learned from experimental data, providing an easy way to realize convolution by broadening functions modeling size-strain sample effects, possibly anisotropic). Equipartition of exactly overlapping reflections comes from the strictly equal result from the above noted equation for Bragg peaks at the same angles which would have starting equal calculated intensities. Not starting from a set of all equal $S_{K}^{2}\left(\right.$ calc) values would produce $I_{K}(\mathrm{obs})$ values keeping the same original ratio for the exactly overlapping reflections. It is understandable that such an iterative process requires as good starting cell and profile parameters as the Rietveld method itself. The process is easier to incorporate inside of an existing Rietveld code than the Pawley method, so that most Rietveld codes propose now the structure factor amplitudes extraction as an option (generally multiphase, with the possibility to com- bine a Rietveld refinement together with a Le Bail fit). A list of programs (1990-1995) applying this method (either exclusively or added inside of a Rietveld code) includes MPROF (Jouanneaux et al., 1990), later renamed WINMPROF, FULLPROF (Rodriguez-Carvajal, 1990), EXTRACT (Baerlocher, 1990), EXTRA (Altomare et al., 1995), and EXPO (Altomare et al., 1999a) which is the integration of EXTRA and SIRPOW.92 for solution and refinement of crystal structures. Then followed most well-known Rietveld codes (BGMN, GSAS, MAUD, TOPAS, etc.) or standalone programs (AJUST by Rius et al., 1996). From the Giacovazzo group in Italy, many improvements were incorporated during the following years in the pattern decomposition Le Bail method: by obtaining information about the possible presence of preferred orientation by the statistical analysis of the normalized structure factor moduli (Altomare et al., 1994); by using the positivity of the Patterson function inside of the decomposition process (Altomare et al., 1998), this having been considered previously (David, 1987; Eastermann et al., 1992; Eastermann and Gramlich, 1993; Easterman and David, 2002); by the characterization of pseudotranslational symmetry used as prior information in the pattern decomposition process (Altomare et al., 1996a); by multiple Le Bail fits with random attribution of intensity to the overlapping reflections, instead of equipartition, followed by application of direct method to large numbers of such data sets (Altomare et al., 2001, 2003, 2004); by the use of a located structure fragment for improving the pattern decomposition process (Altomare et al., 1999 ); by the use of probability (triplet-invariant distribution functions) integrated (Carrozzini et al., 1997) with the Le Bail algorithm. The list of structure solutions made from intensities extracted by using the Le Bail method is too long to be given here, but can be found on the Internet (Le Bail, 2005b). The pattern corresponding to the first application (Le Bail et al., 1988) to the structure solution of $\mathrm{LiSbWO}_{6}$ is shown in Figure 1, the fit being realized with the FULLPROF (Rodriguez-Carvajal, 1990) and WINPLOTR (Roisnel and Rodriguez-Carvajal, 2001) programs instead of ARITB, originally applied.

\section{Comparisons of the Pawley and Le Bail methods}

The Giacovazzo group considered (Altomare et al., 1996b) that pattern -decomposition programs based on the Le Bail algorithm are able to exploit the prior information in a more effective way than Pawley-method-based decomposition programs. Other comparisons of both methods can be found by Giacovazzo (1996) and David and Sivia (2002), the latter finding that the Le Bail method could as well lead to negative intensities in ranges of the pattern where the background is overestimated (i.e., if the-observed minus background-difference pattern presents negative values, which a user should be careful-enough to avoid). Another approach for solving the overlapping problem was proposed by using maximum-entropy coupled with likelihood evaluation (Dong and Gilmore, 1998). The fact is that both the Pawley and Le Bail methods are able to estimate structure factor amplitudes which can lead to solve structures from powder diffraction data in a quite more efficient way than was previously possible, even if the overlapping handicap precludes forever attainment of the single crystal data quality level. The small number of successful participants to the 


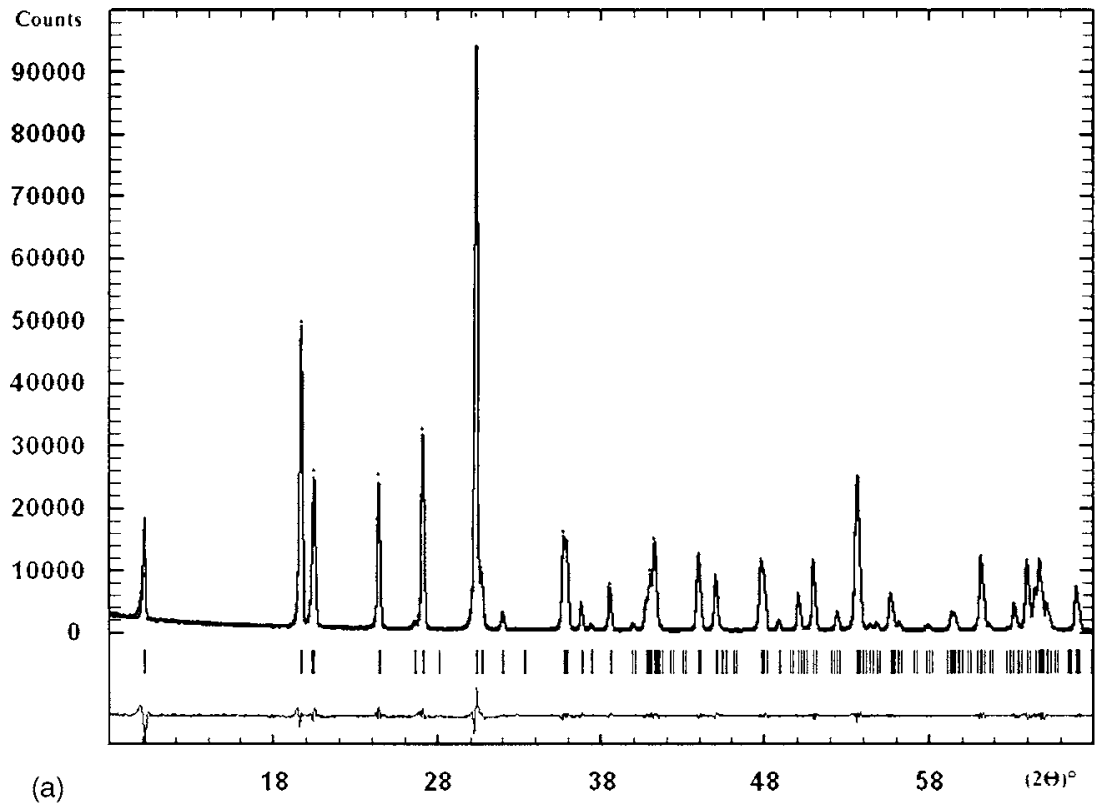

Figure 1. Le Bail fit of the powder pattern of $\mathrm{LiSbWO}_{6}$, the first structure solved (Le Bail et al., 1988) from intensities extracted by iterations of the

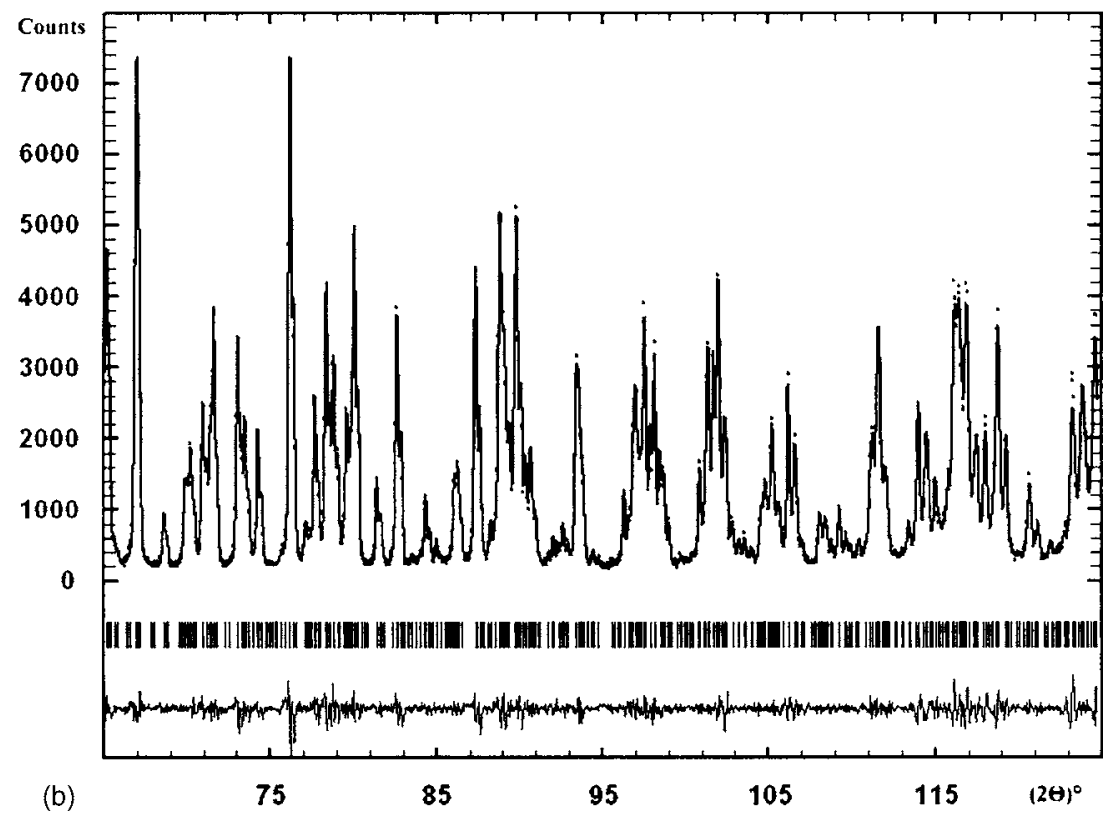

SDPD round robins held in 1998 and 2002 (Le Bail and Cranswick, 2001, 2003) did not allow one to conclude if there is really one approach better than the other or even to be sure if all the further modifications are really decisive improvements (the conclusion was that SDPD "on demand" was still not an easy task), though WPPD is not the only reef on the SDPD route.

\section{MOST CITED PAPERS CITING THE WPPD METHODS}

Summarizing, the first modern WPPD method, with cell restraint, was developed for neutron data by Pawley (1981), this is 12 years after the Rietveld (1969) method publication. In 1988 (Le Bail et al.), a new WPPD approach is applied to extract intensities making use of iterations of the Rietveld decomposition formula. So, it is clear that both these WPPD methods are children of the Rietveld method. Nowadays, most users of the Rietveld method do not cite the original Rietveld papers, but give only a reference to the software they used. This is also now increasingly the case for the WPPD methods. From the Thomson-ISI citation index consulted in December 2004, the reference papers for the Pawley and Le Bail methods scored, respectively, 322 and 493 citations. Interesting as well are the highly cited papers citing these two previous ones. The most cited paper ( $>1300$ times) citing both WPPD methods advocates for the use of this intensity extraction method for solving magnetic structures (Rodriguez-Carvajal, 1993). This suggests that we could more easily understand the influence of the WPPD methods by studying positive citations of them. The most cited papers (classified in decreasing order down to more than 100 citations) citing either the Pawley or Le Bail methods, or both, are reported in Table I. The most cited paper about magnetism (Rodriguez-Carvajal, 1993), at the top of the list, in fact is about the Rietveld program FULLPROF, only 
TABLE I. Most cited papers citing either the Pawley, Le Bail method, or both.

\begin{tabular}{|c|c|c|c|c|c|}
\hline $\begin{array}{l}\text { Citation } \\
\text { numbers }\end{array}$ & Author(s) & Year & Topic & Citing Pawley & Citing Le Bail \\
\hline$>1300$ & Rodriguez-Carvajal & 1993 & Magnetism/software (FULLPROF) & $\times$ & $\times$ \\
\hline$>400$ & Radaelli et al. & 1997 & Application to magnetism & & $\times$ \\
\hline$>300$ & Toraya & 1986 & Software (WPPF) & $\times$ & \\
\hline$>300$ & Izumi and Ikeda & 2000 & Software (RIETAN) & $x$ & $x$ \\
\hline$>200$ & Altomare et al. & 1995 & Software (EXTRA) & $\times$ & $\times$ \\
\hline$>150$ & Subramanian et al. & 1996 & Application to magnetism & & $\times$ \\
\hline$>150$ & Altomare et al. & $1999 a$ & Software (EXPO) & & $\times$ \\
\hline$>100$ & Langford and Louër & 1996 & Review on powder diffraction & $x$ & $x$ \\
\hline$>100$ & Pagola et al. & 2000 & Application to SDPD & & $x$ \\
\hline$>100$ & Christensen et al. & 1990 & Application to SDPD & $\times$ & \\
\hline$>100$ & Evans et al. & 1996 & Thermal expansion study & & $x$ \\
\hline$>100$ & Harris and Tremayne & 1996 & Review on SDPD & $x$ & $x$ \\
\hline$>100$ & McCusker et al. & 1999 & Rietveld guidelines & $x$ & $\times$ \\
\hline$>100$ & Stephens & 1999 & Anisotropic peak broadening & & $x$ \\
\hline
\end{tabular}

applying the Le Bail method (though citing also the Pawley method) in order to get precise integrated intensities and refine the propagation vector(s) of the magnetic structure. The more than 1300 papers citing it probably do not realize full magnetic structure determinations in that way, so this is hard to evaluate. In the second most highly cited paper (cited $>400$ times), the WPPD method was used to help analyzing synchrotron and neutron powder patterns of $\mathrm{La}_{0.5} \mathrm{Ca}_{0.5} \mathrm{MnO}_{3}$, and there is also another application to magnetism in the list (Subramanian et al., 1996). The three next most cited papers are about software: the paper on the computer program WPPF, by Toraya (1986), is even more frequently cited than the original Pawley paper of which it adapts the method to X-ray data; RIETAN, a highly applied Japanese Rietveld program, implementing WPPD; and EXTRA citing both Pawley and Le Bail methods, but implementing the Le Bail method only. The next paper in Table $\mathrm{I}$ is a famous review on powder diffraction by Langford and Louër (1996) from which the following can be extracted:

A major advance in recent years has occurred in the determination of crystal structures ab initio from powder diffraction data, in cases where suitable single crystals are not available. This is a consequence of progress made in the successive stages involved in structure solution, e.g. the development of computer-based methods for determining the crystal system, cell dimensions and symmetry (indexing) and for extracting the intensities of Bragg reflections, the introduction of high resolution instruments and the treatment of line-profile overlap by means of the Rietveld method. However, the intensities obtained, and hence the moduli of the observed structure factors, are affected by the overlap problem, which can seriously frustrate the determination of an unknown crystal structure. Although numerous structures have been solved from powder data by using direct or Patterson methods, the systematic or accidental total overlap of reflections continues to focus the attention of a number of crystallographers. New approaches for the treatment of powder data have been devised, based on maximum entropy methods and "simulated annealing," for example, to generate structural models.
Those "simulated annealing" methods are now included in the category of structure solution by "direct space methods" which are either using the original diffraction pattern or extracted intensities by the WPPD methods inserted into mathematical expressions defining correlations induced by the overlapping degree. These equations were developed by David et al. (1998) for the Pawley method and Pagola et al. (2000) for the Le Bail method. But, even if the raw pattern is used, applications of either the Pawley or Le Bail methods are necessary in order to estimate the zero point, cell, profile shape, and width parameters, etc., which will be fixed later, during the global optimization process, when searching for the minimum $R$ factor. By the way, the paper by Pagola et al. (2000) appears in Table I as one of the most cited applications reporting the crystal structure of $\beta$-haematin determined using simulated annealing techniques to analyses powder diffraction data obtained with synchrotron radiation. This result has implications for understanding the action of current antimalarial drugs and possibly for the design of new therapeutic agents. Next in Table I is the Christensen et al. (1990) paper on the SDPD of $\gamma-\mathrm{TiH}_{2} \mathrm{P}_{2} \mathrm{O}_{8} \cdot 2 \mathrm{H}_{2} \mathrm{O}$, using the Pawley method. Then ranked is the thermal expansion study of $\mathrm{ZrW}_{2} \mathrm{O}_{8}$ and $\mathrm{HfW}_{2} \mathrm{O}_{8}$ by Evans et al. (1996). It can be much faster to use WPPD rather than the Rietveld method, moreover if some systematic error occurs, like preferred orientation. However, it is not recommended to do this systematically, especially if the structure is complex and the resolution is low (see the warnings in a paper from Peterson, 2005). Next is the most cited review on SDPD from Harris and Tremayne (1996). More than 30 such reviews were published during the last 15 years, a list can be found in the SDPD database (Le Bail, 2005b), but cannot be reproduced here. Next is the paper from the IUCr Powder Diffraction Commission providing guidelines for the Rietveld method (McCusker et al., 1999): about the Rietveld $R_{W P}$ value, it is said that it should approach the value obtained in a structurefree refinement (i.e., using WPPD methods) which is recommended for the estimation of initial values for the Rietveld profile parameters, etc. This is what is done in the last paper (Stephens, 1999) in Table I, obtaining the best $R_{W P}$ in a difficult case with anisotropic line broadening by a new phenomenological approach. The list of these highly cited pa- 
pers citing the WPPD methods is probably incomplete if some works were using these methods but did not cite them. Moreover, papers citing the computer programs WPPF, EXTRA, EXPO, etc., which are quite numerous as well, were not examined (though they correspond generally to WPPD applications).

\section{MORE WPPD APPLICATIONS}

The list of the possible different kinds of WPPD applications is impressive (see for instance a review paper by Toraya, 1994), including phase identification, quantitative phase analysis, refinement of unit-cell parameters, measurement of crystallite sizes and strains, determination of space group, $a b$ initio structure determination, Fourier maps for partially solved structures, structure refinement by the twostep method, and study on electron density distribution, using either the Pawley or Le Bail methods. In the SDPD maze (David et al., 2002), there is no other path than to use at least one of them. WPPD has even entered into the indexing step with Kariuki et al. (1999) using the Le Bail fit for testing, faster than with the Pawley method, cell hypotheses in a new computer program applying a genetic algorithm. With both methods, the fit quality is checked from agreement factors which are the same as with the Rietveld method: $R_{P}, R_{W P}$, $R_{\text {EXP }}$ (moreover, a visual careful check is recommended). The reliabilities relative to the structure $\left(R_{B}\right.$ and $\left.R_{F}\right)$, which can still be calculated, are meaningless (both programs tending to obtain a value close to zero for both of them). It is recommended (Hill and Fisher, 1990) to have confidence preferably in the original Rietveld estimated profile $R$ factors (calculated after background subtraction, and removing "nonpeak" regions). If WPPD methods provide help in cell parameter refinement and determination of space group, the main application is the extraction of intensities for $a b$ initio structure solution purpose, or at least for the establishment of the profile parameters to be used in a direct-space solution program exploiting a raw powder pattern (these WPPD methods will provide the smallest profile $R$ factors attainable, smaller than those which will be obtained at the Rietveld method final step). With neutron data, besides solving the nuclear structure, the FULLPROF program allows for solving magnetic structures as well (Rodriguez-Carvajal, 1993). Reusing extracted intensities for structure solution by direct space methods can be made in a way that is not sensitive to the equipartitioning problems. This was done in the ESPOIR program (Le Bail, 2001) by regenerating a powder pattern from the extracted "|Fobs|," using a simple Gaussian peak shape whose width follows the Caglioti law established from the raw pattern. With such a pseudo powder pattern, without profile asymmetry, background, etc., the calculations are much faster than if the raw pattern was used. In another direct-space structure solution program, PSSP (Pagola et al., 2000), based on the Le Bail method as well, an agreement factor allowing one to define the best model takes account of the overlap significant for nearby peaks. In DASH, a similar method (David et al., 1998) is applied to the intensities extracted by the Pawley method, through the use of the correlation matrix. When using the direct methods instead of the direct-space methods, approaches are different, because the direct methods necessitate the more complete possible data set (up to $d=1 \AA$ ) of accurate "|Fobs|." However, removing up to half of them (those with too much overlapping, i.e., being too nearby than 0.5 full width at half maximum, for instance) is possible while obtaining some success with the direct methods (one can even remove up to $70-80 \%$ if the Patterson method is applied and if only a small number of heavy atoms are to be located). David (2004) provided a demonstration recently of the equivalence of the Rietveld method and the correlated intensities method in powder diffraction. It is unlikely that this demonstration, related to the old two-stage controversy, could lead one to abandon the Rietveld method, however, research is still being conducted on that question (Wright, 2004). Another application of WPPD is for the data generation used for Fourier map calculations for structure completion. The "|Fobs|" are estimated at the end of a Rietveld refinement by the Rietveld decomposition formula, so that the exactly overlapping reflections are given intensities in the same ratio as they are calculated from the structural model. The Le Bail method could be applied here, performing more than only one iteration of the decomposition formula, which could be insufficient for attaining the minimum $R_{W P}$ if there is a large discrepancy between the observed and calculated patterns. Calculations of electron density distributions from powder data benefit as well from the WPPD methods. Finally, it may be interesting to realize size-strain analysis together with WPPD, if the structure model cannot provide a very good fit, or when systematic errors distort the observed intensities. However, without such systematic errors (preferred orientation), the structure constraint will at least impose an almost correct intensity to overlapping peaks, which is not the case of both the Pawley and Le Bail methods, so that the structure constraint may preclude errors in attributing a wrong broadening to some peaks with exact overlapping. Prudence is thus recommended. Including size-strain analysis in WPPD requires the use of a special formula for taking account of the angular variation of the full width at half maximum or of the integral breadth, the same formula used with the Rietveld method: either the so-called TCH (Thompson et al., 1987) formula (with different angular dependence for the Gaussian and Lorentzian components of a pseudo-Voigt) or the Young and Desai (1989) formula, recommending the use of both $G$ and $L$ components for both size and microstrain effects.

SDPD is the major topic where WPPD methods are indispensable. In Louër's group, using WPPD with cell restraint was mainly by the Le Bail method applied in FULLPROF (or EXTRA and EXPO later). The very first SDPD realized by using FULLPROF was made in this team in 1992 . Citing only a few of the first SDPDs using WPPD methods and made in the range 1988-1994, one can find nine publications in the Louër's group (Louër et al., 1992; Petit et al., 1993, 1994; Pivan et al., 1994; Pelloquin et al., 1994; Guillou et al., 1994; Gascoigne et al., 1994; Bénard et al., 1994a, b), this is a quite large contribution since, in these times, the number of SDPDs per year was small (Figure 2). These applications certainly contributed to making it more widely known that a difficult step (WPPD) was now realized more easily by using a well-distributed Rietveld computer program (FULLPROF). 150 kilometers from Rennes, people were working with a lesser known computer program, ARITB, since 1987, publishing a lot of SDPDs from 1988-1993 (and 


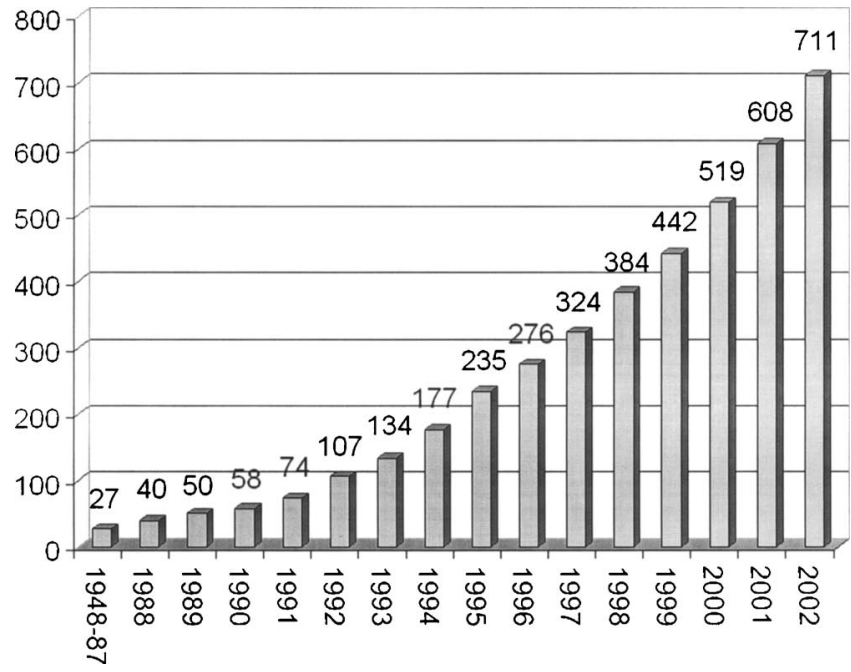

Figure 2. Cumulative histogram of the estimated number of structures determined $a b$ initio by powder diffractometry (from the SDPD-Database).

later), based on the application of WPPD (Le Bail et al., 1988; Laligant et al., 1988a, b; Amoros et al., 1988; Le Bail, 1989; Le Bail et al., 1989a, b; Laligant et al., 1989; Fourquet et al., 1989; Le Bail and Lafontaine, 1990; Le Bail et al., 1990; Lafontaine et al., 1990; Pizarro et al., 1991; Jouanneaux et al., 1991; Laligant et al., 1991; Gao et al., 1992; Laligant, 1992a, b; Le Bail et al., 1992a, b; Bentrup et al., 1992; Le Bail, 1993; Laligant and Le Bail, 1993), and more publications came after, changing from ARITB to FULLPROF. At Nantes, $200 \mathrm{~km}$ from Le Mans, they used MPROF (ZahLetho et al., 1992; Jouanneaux et al., 1992a; Le Bideau et al., 1993). Other applications using the Le Bail method introduced into other programs (GSAS, etc), or using ARITB outside of Le Mans are numerous as well (Hriljac et al., 1991; Aranda et al., 1992; Jouanneaux et al., 1992b; Lightfoot et al., 1992a, b; Morris et al., 1992; Teller et al., 1992; Tremayne et al., 1992a, b; Williams et al., 1992; Abrahams et al., 1993; Aftati et al., 1993; Baumgartner et al., 1993; Harrison et al., 1993; Hriljac and Torardi, 1993; Lightfoot et al., 1993). Elsewhere, they used the Pawley method with the ALLHKL, PAWHKL, PAWSYN, CAILS, etc., programs (Lehmann et al., 1987; McCusker, 1988; Christensen et al., 1989, 1990; Lightfoot et al., 1991; Simmen et al., 1991; Norby et al., 1991; Christensen et al., 1991; Fjellvàg and Karen, 1992; Fitch and Cockroft, 1992; Clarke et al., 1993, Delaplane et al., 1993). Some SDPDs were also realized by using the WPPF software (from Toraya) (Hiraguchi et al., 1991; Masciocchi et al., 1993). A more complete list is available in the SDPD-Database (Le Bail, 2005a). In the above-noted list, one finds 58 SDPDs realized by using either the Pawley or Le Bail methods out of a total of 107 SDPDs in the period 1988-1993. Most other applications concern in general more simple structures determined by using pattern decomposition methods without cell constraint, or trial and error approaches, modeling, guessing, or the procedures applied were not explained. After those early contributions, acceleration is obvious on Figure 2. Those past 20 years have seen more than 1000 SDPDs published. There was clearly a race for the announcement of the biggest SDPD ever determined, and, of course, the winner was constantly changing, many papers were published in prestigious journals (Nature, Sci- ence). Morris et al. (1992) reported the SDPD of a gallium phosphate, showing that a 29 independent atoms structure could be determined by combining synchrotron and neutron data (the previous record was 17 atoms). Le Bail (1993) solved the $\beta-\mathrm{Ba}_{3} \mathrm{AlF}_{9}$ structure, showing that 29 independent atoms were possible as well from conventional diffraction data. Morris et al. (1994) reported then a 60-atoms structure, $\mathrm{La}_{3} \mathrm{Ti}_{5} \mathrm{Al}_{15} \mathrm{O}_{37}$. Much later, a 117-atom structure was reported, the zeolite UTD-1F (Wessels et al., 1999) from the simultaneous use of five diffraction patterns collected from different preferred orientations of the same sample (the data were thus closer to a conventional single crystal data set). Then people solving structures in direct space claimed that extracting intensities was no longer necessary since they fitted the raw pattern directly from their model, forgetting to say that the profile shape and width parameters were previously estimated by WPPD methods. Other showed that it may be faster to use extracted intensities, or a pseudopowder pattern regenerated from them, rather than to use the raw data. The story is really not ending. It seems however that the number of innovations is decreasing by now, in that SDPD domain. Interested people dispose of an impressive arsenal of computer programs. Protein structures are now refined, some being solved (Von Dreele et al., 2000), leading to a new record: 1630 independent atoms. It is now said that solving structures without single crystal data may need powder data for refinement but not necessarily for structure solution, the solution being obtained by prediction for either organic (Motherwell et al., 2002) or inorganic (Le Bail, $2005 \mathrm{c}$ ) compounds. There is a bit of an exaggeration there, probably, again, and progress has to be made. However, prediction is certainly an unavoidable route, provided we can predict everything, and build a search/matchable database of predicted powder patterns. Predicting properties would allow for the selection of the most interesting compounds reducing efforts to synthesize them only. Of course the structure solution is the ultimate proof that a cell is correct (or that a prediction is correct), and the more a structure is complex leading to high overlapping, the more uncertainties will occur on the cell parameters values (as well on the extracted intensities) if one limits himself/herself to WPPD Pawley or Le Bail applications. The structure constraint will remove the ambiguity between intensities of close Bragg peaks and necessarily improve the cell parameters quality. It is possible to present cases where the Pawley or Le Bail results are shown to be much less accurate than using the Rietveld method for series of temperature dependent measurements (Peterson, 2005). If the structure is known, the best approach is the Rietveld method. We can say that there is a progression in the precision of the refined cell parameters from a lowest level (least-squares from extracted peak positions) to a medium level (WPPD with cell restraint) and to the highest possible level (Rietveld, adding the structure constraint).

\section{CONCLUSION}

All these efforts in order to be able to extract the maximum information from a powder pattern may look incredible. Especially, developing the WPPD methods, applied just after the indexing bottleneck, have led to an expansion of our abilities in SDPD from 1987 to 1993. Then the direct-space 
methods have given a second acceleration, but this is another story. The WPPD methods continue to be used extensively. It can be said that the main whole powder pattern fitting methods (decomposition or Rietveld methods) have attained their cruise speed, enabling the structure determination (almost routinely) and refinement (routinely) of moderately complex structures to even complex crystal structures (proteins), sometimes, these main topics being only a part of their large application range to the characterization of crystallized materials in powder form. Because of these advances in pattern decomposition and structure solving, "indexing is increasingly the limiting step in determining ab initio crystal structures from powders" (Shirley, 2004).

Abrahams, I., Lightfoot, P., and Bruce, P. G. (1993). " $\mathrm{Li}_{6} \mathrm{Zr}_{2} \mathrm{O}_{7}$, a new anion vacancy ccp based structure, determined by ab initio powder diffraction methods," J. Solid State Chem. 104, 397-403.

Aftati, A., Champarnaud-Mesjard, J.-C., and Frit, B. (1993). "Crystal structure of a new oxyfluoride, $\mathrm{Cd}_{4} \mathrm{~F}_{6} \mathrm{O}$ : Relations to the fluorite and the $\beta-\mathrm{Bi}_{2} \mathrm{O}_{3}$ types," Eur. J. Solid State Inorg. Chem. 30, 1063-1073.

Altomare, A., Burla, M. C., Camalli, M., Carrozzini, B., Cascarano, G. L., Giacovazzo, C., Guagliardi, A., Moliterni, A. G. G., Polidori, G., and Rizzi, R. (1999a). "EXPO: A program for full powder pattern decomposition and crystal structure solution," J. Appl. Crystallogr. 32, 339-340.

Altomare, A., Burla, M. C., Cascarano, G., Giacovazzo, C., Guagliardi, A., Moliterni, A. G. G., and Polidori, G. (1995). "EXTRA: A program for extracting structure-factor amplitudes from powder diffraction data," J. Appl. Crystallogr. 28, 842-846.

Altomare, A., Caliandro, R., Cuocci, C., da Silva, L., Giacovazzo, C., Moliterni, A. G. G., and Rizzi, R. (2004). "The use of error-correcting codes for the decomposition of a powder diffraction pattern," J. Appl. Crystallogr. 37, 204-209.

Altomare, A., Caliandro, R., Cuocci, C., Giacovazzo, C., Moliterni, A. G. G., and Rizzi, R. (2003). "A systematic procedure for the decomposition of a powder diffraction pattern," J. Appl. Crystallogr. 36, 906-913.

Altomare, A., Carrozzini, B., Giacovazzo, C., Guagliardi, A., Moliterni, A. G. G., and Rizzi, R. (1996b). "Solving crystal structures from powder data. I. The role of the prior information in the two-stage method," J. Appl. Crystallogr. 29, 667-673.

Altomare, A., Cascarano, G., Giacovazzo, C., and Guagliardi, A. (1994). "Early finding of preferred orientation: A new method," J. Appl. Crystallogr. 27, 1045-1050.

Altomare, A., Foadi, J., Giacovazzo, C., Guagliardi, A., and Moliterni, A. G. G. (1996a). "Solving crystal structures from powder data. II. Pseudotranslational symmetry and powder-pattern decomposition," J. Appl. Crystallogr. 29, 674-681.

Altomare, A., Foadi, J., Giacovazzo, C., Moliterni, A. G. G., Burla, M. C., and Polidori, G. (1998). "Solving crystal structures from powder data. IV. The use of the Patterson information for estimating the $|F|$ 's," J. Appl. Crystallogr. 31, 74-77.

Altomare, A., Giacovazzo, C., Guagliardi, A., Moliterni, A. G. G., and Rizzi, R. (1999b). "Solving crystal structures from powder data V. Located molecular fragment and powder-pattern decomposition," J. Appl. Crystallogr. 32, 963-967.

Altomare, A., Giacovazzo, C., Moliterni, A. G. G., and Rizzi, R. (2001). "A random procedure for the decomposition of a powder pattern in EXPO," J. Appl. Crystallogr. 34, 704-709.

Amoros, P., Beltran-Porter, D., Le Bail, A., Férey, G., and Villeneuve, G. (1988). "Crystal structure of $\mathrm{A}\left(\mathrm{VO}_{2}\right)\left(\mathrm{HPO}_{4}\right)\left(\mathrm{A}=\mathrm{NH}^{4+}, \mathrm{K}^{+}, \mathrm{Rb}^{+}\right)$solved from X-ray powder diffraction," Eur. J. Solid State Inorg. Chem. 25, $599-607$.

Aranda, M. A. G., Attfield, J. P., and Bruque, S. (1992). "A remarkable change in framework cation position upon lithium exchange: The crystal structure of $\mathrm{LiMnPO}_{4}(\mathrm{OH})$," Angew. Chem., Int. Ed. Engl. 31, 10901092.

Baerlocher, Ch. (1990). "EXTRACT, A FORTRAN program for the extraction of integrated intensities from a powder pattern," Institut für Kristallograpie, ETH, Zürich, Switzerland.

Baumgartner, M., Schmalle, H., and Baerlocher, Ch. (1993). "Synthesis, characterization, and crystal structure of three homoleptic copper(I) thiolates: $\quad\left(\mathrm{Cu}\left(\mathrm{CH}_{3} \mathrm{~S}^{-}\right)\right)_{n}, \quad\left[\left(\mathrm{C}_{6} \mathrm{H}_{5}\right)_{4} \mathrm{P}^{+}\right]_{2}\left[\mathrm{Cu}_{5}\left(\mathrm{CH}_{3} \mathrm{~S}^{-}\right)_{7}\right]$ . $\mathrm{C}_{2} \mathrm{H}_{6} \mathrm{O}_{2}$, and $\left[\left(\mathrm{C}_{3} \mathrm{H}_{7}\right)_{4} \mathrm{~N}^{+}\right]_{2}\left[\mathrm{Cu}_{4}\left(\mathrm{CH}_{3} \mathrm{~S}^{-}\right)_{6}\right] \cdot \mathrm{CH}_{4} \mathrm{O}$," J. Solid State
Chem. 107, 63-75.

Bénard, P., Louër, D., Dacheux, N., Brandel, V., and Genet, M. (1994a). " $\mathrm{U}\left(\mathrm{UO}_{2}\right)\left(\mathrm{PO}_{4}\right)_{2}$, a new mixed-valence uranium orthophosphate, $a b$ initio structure determination from powder diffraction data and optical and X-ray photoelectron spectra," Chem. Mater. 6, 1049-1058.

Bénard, P., Louër, M., and Louër, D. (1991). "Crystal structure determination of $\mathrm{Zr}(\mathrm{OH})_{2}\left(\mathrm{NO}_{3}\right)_{2.4} \cdot 7 \mathrm{H}_{2} \mathrm{O}$ from X-ray powder diffraction data," J. Solid State Chem. 94, 27-35.

Bénard, P., Seguin, L., Louër, D., and Figlarz, M. (1994b). "Structure of $\mathrm{MoO}_{3} \cdot 1 / 2 \mathrm{H}_{2} \mathrm{O}$ by conventional X-ray powder diffraction," J. Solid State Chem. 108, 170-176.

Bentrup, U., Le Bail, A., Duroy, H., and Fourquet, J. L. (1992). "Polymorphism of $\mathrm{CsAlF}_{4}$. Synthesis and structure of two new crystalline forms," Eur. J. Solid State Inorg. Chem. 29, 371-381.

Bergmann, J., Le Bail, A., Shirley, R., and Zlokazov, V. (2004). "Renewed interest in powder diffraction data indexing," Z. Kristallogr. 219, 783790.

Byrom, P. G. and Lucas, P. W. (1993). "POLISH: Computer program for improving the accuracy of structure-factor magnitudes obtained from powder data," J. Appl. Crystallogr. 26, 137-139.

Caglioti, G., Paoletti, A., and Ricci, F. P. (1958). "Choice of collimators for a crystal spectrometer for neutron diffraction," Nucl. Instrum. 3, 223228.

Carrozzini, B., Giacovazzo, C., Guagliardi, A., Rizzi, R., Burla, M. C., and Polidori, G. (1997). "Solving crystal structures from powder data. III. The use of the probability distributions for estimating the $|F|$ 's," J. Appl. Crystallogr. 30, 92-97.

Cheary, R. W. and Coelho, A. (1992). "A fundamental parameters approach to X-ray line-profile fitting,” J. Appl. Crystallogr. 25, 109-121.

Christensen, A. N., Andersen, E. K., Andersen, I. G. K., Alberti, G., Nielsen, M., and Lehmann, M. S. (1990). "X-ray-powder diffraction study of layer compounds-The crystal structure of $\alpha$-Ti( $\left(\mathrm{HPO}_{4}\right)_{2} \cdot \mathrm{H}_{2} \mathrm{O}$ and a proposed structure for $\gamma$ - $\mathrm{Ti}\left(\mathrm{H}_{2} \mathrm{PO}_{4}\right)\left(\mathrm{PO}_{4}\right) \cdot 2 \mathrm{H}_{2} \mathrm{O}$," Acta Chem. Scand. 44, 865-872.

Christensen, A. N., Cox, D. E., and Lehmann, M. S. (1989). "A crystal structure determination of $\mathrm{PbC}_{2} \mathrm{O}_{4}$ from synchrotron X-ray and neutron powder diffraction data," Acta Chem. Scand. 43, 19-25.

Christensen, A. N., Hazell, R. G., Hewat, A. W., and O'Reilly, K. P. J. (1991). "The crystal structure of $\mathrm{PbS}_{2} \mathrm{O}_{3}$," Acta Scand. 45, 469-473.

Clarke, S. J., Cockcroft, J. K., and Fitch, A. N. (1993). "The structure of solid $\mathrm{CF}_{3} \mathrm{I}$," Z. Kristallogr. 206, 87-95.

Cooper, M. J., Rouse, K. D., and Sakata, M. (1981). "An alternative to the Rietveld profile refinement method," Z. Kristallogr. 157, 101-117.

David, W. I. F. (1987). "The probabilistic determination of intensities of completely overlapping reflections in powder diffraction patterns," $\mathrm{J}$. Appl. Crystallogr. 20, 316-319.

David, W. I. F. (2004). "On the equivalence of the Rietveld method and the correlated integrated intensities method in powder diffraction," J. Appl. Crystallogr. 37, 621-628.

David, W. I. F., Shankland, K., McCusker, L. B., and Baerlocher, Ch. (2002). in Structure Determination from Powder Diffraction Data, edited by W. I. F. David, K. Shankland, L. B. McCusker, and Ch. Baerlocher (Oxford Science, Oxford), Chap. 1, pp. 1-12.

David, W. I. F., Shankland, K. and Shankland, N. (1998). "Routine determination of molecular crystal structures from powder diffraction data," Chem. Commun. (Cambridge), 931-932.

David, W. I. F. and Sivia, D. S. (2002). in Structure Determination from Powder Diffraction Data, edited by W. I. F. David, K. Shankland, L. B. McCusker, and Ch. Baerlocher (Oxford Science, Oxford), Chap. 8, pp. 136-161.

Delaplane, R. G., David, W. I. F., Ibberson, R. M., and Wilson, C. C. (1993). "The $a b$ initio crystal structure determination of $\alpha$-malonic acid from neutron powder diffraction data," Chem. Phys. Lett. 201, 75-78.

Dong, W. and Gilmore, C. J. (1998). "The ab initio solution of structures from powder diffraction data: The use of maximum entropy and likelihood to determine the relative amplitudes of overlapped reflections using the pseudophase concept," Acta Crystallogr., Sect. A: Found. Crystallogr. 54, 438-446.

Eastermann, M. A. and David, W. I. F. (2002). Structure Determination from Powder Diffraction Data, edited by W. I. F. David, K. Shankland, L. B. McCusker, and Ch. Baerlocher (Oxford Science, Oxford), Chap. 12, pp. 202-218.

Eastermann, M. A. and Gramlich, V. (1993). "Improved treatment of severely or exactly overlapping Bragg reflections for the application of direct methods to powder data," J. Appl. Crystallogr. 26, 396-404. 
Eastermann, M. A., McCusker, L. B., and Baerlocher, Ch. (1992). "Ab initio structure determination from severely overlapping powder diffraction data," J. Appl. Crystallogr. 25, 539-543.

Evans, J. S. O., Mary, T. A., Vogt, T., Subramanian, M. A., and Sleight, A. W. (1996). "Negative thermal expansion in $\mathrm{ZrW}_{2} \mathrm{O}_{8}$ and $\mathrm{HfW}_{2} \mathrm{O}_{8}$," Chem. Mater. 8, 2809-2823.

Fitch, A. N. and Cockcroft, J. K. (1992). "Structure of solid tribromofluoromethane $\mathrm{CFBr}_{3}$ by powder neutron diffraction," Z. Kristallogr. 202, 243-250.

Fjellvàg, H. and Karen, P. (1992). "Crystal structure of magnesium sesquicarbide," Inorg. Chem. 31, 3260-3263.

Fourquet, J. L., Le Bail, A., Duroy, H., and Moron, M. C. (1989). “ $\left(\mathrm{NH}_{4}\right)_{2} \mathrm{FeF}_{5}$, crystal structures of its $\alpha$ and $\beta$ forms," Eur. J. Solid State Inorg. Chem. 26, 435-443.

Gao, Y., Guery, J., and Jacoboni, C. (1992). "X-ray powder structure determination of $\mathrm{NaBaZrF}_{7}$," Eur. J. Solid State Inorg. Chem. 29, 12851293.

Gascoigne, D., Tarling, S. E., Barnes, P., Pygall, C. F., Bénard, P., and Louër, D. (1994). " $A b$ initio structure determination of $\mathrm{Zr}(\mathrm{OH})_{2} \mathrm{SO}_{4} \cdot 3 \mathrm{H}_{2} \mathrm{O}$ using conventional X-ray powder diffraction," J. Appl. Crystallogr. 27, 399-405.

Giacovazzo, C. (1996). "Direct methods and powder data: State of the art and perspectives," Acta Crystallogr., Sect. A: Found. Crystallogr. 52, 331-339.

Guillou, N., Louër, M., and Louër, D. (1994). “An X-ray and neutron powder diffraction study of a new polymorphic phase of copper hydroxide nitrate," J. Solid State Chem. 109, 307-314.

Harris, K. D. M. and Tremayne, M. (1996). "Crystal structure determination from powder diffraction data," Chem. Mater. 8, 2554-2570.

Harrison, W. T. A., Gier, T. H., and Stucky, G. D. (1993). "The synthesis and ab initio structure determination of $\mathrm{Zn}_{4} \mathrm{O}\left(\mathrm{BO}_{3}\right)_{2}$, a microporous zincoborate constructed of fused subunits of three- and five-membered rings," Angew. Chem., Int. Ed. Engl. 32, 724-726.

Hill, R. J. and Fisher, R. X. (1990). "Profile agreement indices in Rietveld and pattern-fitting analysis," J. Appl. Crystallogr. 23, 462-468.

Hiraguchi, H., Hashizume, H., Fukunaga, O., Takenaka, A., and Sakata, M. (1991). "Structure determination of magnesium boron nitride, $\mathrm{Mg}_{3} \mathrm{BN}_{3}$, from X-ray powder diffraction data,” J. Appl. Crystallogr. 24, 286-292.

Hriljac, J. A., Parise, J. B., Kwei, G. H., and Schwartz, K. B. (1991). "The $a b$ initio crystal structure determination of $\mathrm{CuPt} \mathrm{O}_{6}$ from a combination of synchrotron X-ray and neutron powder diffraction data," J. Phys. Chem. Solids 52, 1273-1279.

Hriljac, J. A. and Torardi, C. C. (1993). "Synthesis and structure of the novel layered oxide $\mathrm{BiMo}_{2} \mathrm{O}_{7} \mathrm{OH} \cdot 2 \mathrm{H}_{2} \mathrm{O}$," Inorg. Chem. 32, 6003-6007.

Izumi, F. and Ikeda, T. (2000). "A Rietveld-analysis program RIETAN-98 and its applications to zeolites," Mater. Sci. Forum 321-3, 198-203.

Jansen, E., Schäfer, W., and Will, G. (1988). "Profile fitting and the twostage method in neutron powder diffractometry for structure and texture analysis," J. Appl. Crystallogr. 21, 228-239.

Jansen, J., Peschar, R., and Schenk, H. (1992). "On the determination of accurate intensities from powder diffraction data. I. Whole-pattern fitting with a least-squares procedure; and II. Estimation of intensities of overlapping reflections," J. Appl. Crystallogr. 25, 231-236 and 237-243.

Jouanneaux, A., Fitch, A. N., and Cockcroft, J. K. (1992b). "The crystal structure of $\mathrm{CBrF}_{3}$ by high-resolution powder neutron diffraction," Mol. Phys. 1, 45-50.

Jouanneaux, A., Joubert, O., Evain, M., and Ganne, M. (1992a). "Structure determination of $\mathrm{Tl}_{4} \mathrm{~V}_{2} \mathrm{O}_{7}$ from powder diffraction data using an Inel X-ray PSD, stereochemical activity of thallium(I) lone pair," Powder Diffr. 7, 206-211.

Jouanneaux, A., Joubert, O., Fitch, A. N., and Ganne, M. (1991). "Structure determination of $\beta-\mathrm{Tl}_{3} \mathrm{VO}_{4}$ from synchrotron radiation powder diffraction data, stereochemical role of the lone pair of thallium(I)," Mater. Res. Bull. 26, 973-982.

Jouanneaux, A., Murray, A. D., and Fitch, A. N. (1990). Program MProf.

Kariuki, B. M., Belmonte, S. A., McMahon, M. I., Johnston, R. L., Harris, K. D. M., and Nelmes, R. J. (1999). "A new approach for indexing powder diffraction data based on whole-profile fitting and global optimization using a genetic algorithm," J. Synchrotron Radiat. 6, 87-92.

Lafontaine, M.-A., Le Bail, A., and Férey, G. (1990). "Copper containing minerals, I. $\mathrm{Cu}_{3} \mathrm{~V}_{2} \mathrm{O}_{7}(\mathrm{OH})_{2} \cdot 2 \mathrm{H}_{2} \mathrm{O}$, the synthetic homologue of volborthite; crystal structure determination from X-ray and neutron data; structural correlations," J. Solid State Chem. 85, 220-227.

Laligant, Y. (1992a). "Structure determination of $\mathrm{Na}_{2} \mathrm{PdP}_{2} \mathrm{O}_{7}$ from X-ray powder diffraction,” Eur. J. Solid State Inorg. Chem. 29, 83-94.
Laligant, Y. (1992b). "Crystal structure of $\mathrm{Li}_{2} \mathrm{PdP}_{2} \mathrm{O}_{7}$ solved from X-ray powder diffraction," Eur. J. Solid State Inorg. Chem. 29, 239-247.

Laligant, Y., Férey, G., and Le Bail, A. (1991). "Crystal structure of $\mathrm{Pd}\left(\mathrm{NO}_{3}\right)_{2}\left(\mathrm{H}_{2} \mathrm{O}\right)_{2}$," Mater. Res. Bull. 26, 269-275.

Laligant, Y. and Le Bail, A. (1993). "Synthesis and crystal structure of $\mathrm{Li}_{8} \mathrm{Bi}_{2} \mathrm{PdO}_{10}$ determined ab initio from X-ray powder diffraction data," Eur. J. Solid State Inorg. Chem. 30, 689-698.

Laligant, Y., Le Bail, A., and Férey, G. (1989). "Complex palladium oxides. V. Crystal structure of $\mathrm{LiBiPd}_{2} \mathrm{O}_{4}$, an example of three different fourfold coordinations of cations," J. Solid State Chem. 81, 58-64.

Laligant, Y., Le Bail, A., Férey, G., Avignant, D., and Cousseins, J. C. (1988a). "Determination of the crystal structure of $\mathrm{Li}_{2} \mathrm{TbF}_{6}$ from $\mathrm{X}$-ray and neutron powder diffraction. An example of lithium in five-fold coordination," Eur. J. Solid State Inorg. Chem. 25, 551-563.

Laligant, Y., Le Bail, A., Férey, G., Hervieu, M., Raveau, B., Wilkinson, A., and Cheetham, A. K. (1988b). "Synthesis and ab-initio structure determination from X-ray powder data of $\mathrm{Ba}_{2} \mathrm{PdO}_{3}$ with sevenfold coordinated $\mathrm{Ba}^{2+}$. Structural correlations with $\mathrm{K}_{2} \mathrm{NiF}_{4}$ and $\mathrm{Ba}_{2} \mathrm{NiF}_{6}$," Eur. J. Solid State Inorg. Chem. 25, 237-247.

Langford, J. I., Boultif, A., Auffredic, J. P., and Louër, D. (1993). "The use of pattern decomposition to study the combined X-ray diffraction effects of crystallite size and stacking faults in ex-oxalate zinc oxide," J. Appl. Crystallogr. 26, 22-33.

Langford, J. I. and Louër, D. (1991). "High-resolution powder diffraction studies of copper(II) oxide," J. Appl. Crystallogr. 24, 149-155.

Langford, J. I. and Louër, D. (1996). "Powder diffraction,” Rep. Prog. Phys. 59, 131-234.

Langford, J. I., Louër, D., Sonneveld, E. J., and Wisser, J. W. (1986). “Applications of total pattern fitting to a study of crystallite size and strain in zinc oxide powder," Powder Diffr. 1, 211-221.

Le Bail, A. (1989). "Structure determination of $\mathrm{NaPbFe}_{2} \mathrm{~F}_{9}$ by X-ray powder diffraction," J. Solid State Chem. 83, 267-271.

Le Bail, A. (1993). " $\beta-\mathrm{Ba}_{3} \mathrm{AlF}_{9}$, a complex structure determined from conventional X-ray powder diffraction," J. Solid State Chem. 103, 287291.

Le Bail, A. (2001). "ESPOIR: A program for solving structures by Monte Carlo analysis of powder diffraction data," Mater. Sci. Forum 378-381, 65-70.

Le Bail, A. (2005a). "SDPD_Database," http://www.cristal.org/iniref.html

Le Bail, A. (2005b). "Le Bail method full saga," http://www.cristal.org/ iniref/lbm-story

Le Bail, A. (2005c). "Inorganic structure prediction with GRINSP," J. Appl. Crystallogr. 38, 389-395.

Le Bail, A. and Cranswick, L. M. D. (2001). "Revisiting the 1998 SDPD round robin results," IUCr CPD Newsletter 25, 7-9.

Le Bail, A. and Cranswick, L. M. D. (2003). "SDPD round robin 2002 results," IUCr CPD Newsletter 29, 31-34.

Le Bail, A., Duroy, H., and Fourquet, J. L. (1988). "Ab-initio structure determination of $\mathrm{LiSbWO}_{6}$ by X-ray powder diffraction," Mater. Res. Bull. 23, 447-452.

Le Bail, A., Duroy, H., and Fourquet, J. L. (1992a). "Crystal structure and thermolysis of $\mathrm{K}_{2}\left(\mathrm{H}_{5} \mathrm{O}_{2}\right) \mathrm{Al}_{2} \mathrm{~F}_{9}$," J. Solid State Chem. 98, 151-158.

Le Bail, A., Férey, G., Amoros, P., and Beltran-Porter, D. (1989a). "Structure of vanadyl hydrogenphosphate dihydrate $\alpha$ - $\mathrm{VO}\left(\mathrm{HPO}_{4}\right) \cdot 2 \mathrm{H}_{2} \mathrm{O}$ solved from X-ray and neutron powder diffraction,” Eur. J. Solid State Inorg. Chem. 26, 419-426.

Le Bail, A., Férey, G., Amoros, P., Beltran-Porter, D., and Villeneuve, G. (1989b). "Crystal structure of $\beta$ - $\mathrm{VO}\left(\mathrm{HPO}_{4}\right) \cdot 2 \mathrm{H}_{2} \mathrm{O}$ solved from X-ray powder diffraction," J. Solid State Chem. 79, 169-176.

Le Bail, A., Férey, G., Mercier, A.-M., de Kozak, A., and Samouel, M. (1990). "Structure determination of $\beta$ - and $\gamma-\mathrm{BaAlF}_{5}$ by X-ray and neutron powder diffraction, a model for the $\alpha \rightarrow \beta \leftarrow \rightarrow \gamma$ transitions," J. Solid State Chem. 89, 282-291.

Le Bail, A., Fourquet, J. L., and Bentrup, U. (1992b). " $\tau-\mathrm{AlF}_{3}$, crystal structure determination from X-ray powder diffraction data. A new $\mathrm{MX}_{3}$ corner-sharing octahedra 3D network," J. Solid State Chem. 100, 151159.

Le Bail, A. and Lafontaine, M.-A. (1990). "Structure determination of $\mathrm{NiV}_{2} \mathrm{O}_{6}$ from X-ray powder diffraction, a rutile-ramsdellite intergrowth," Eur. J. Solid State Inorg. Chem. 27, 671-680.

Le Bideau, J., Bujoli, B., Jouanneaux, A., Payen, C., Palvadeau, P., and Rouxel, J. (1993). "Preparation and structure of $\mathrm{Cu}^{\mathrm{II}}\left(\mathrm{C}_{2} \mathrm{H}_{5} \mathrm{PO}_{3}\right)$. Structural transition between its hydrated and dehydrated forms," Inorg. Chem. 32, 4617-4620.

Lehmann, M. S., Christensen, A. N., Fjellvag, H., Feidenhans'1, R., and 
Nielsen, M. (1987). "Structure determination by use of pattern decomposition and the Rietveld method on synchrotron X-ray and neutron powder data; The structures of $\mathrm{Al}_{2} \mathrm{Y}_{4} \mathrm{O}_{9}$ and $\mathrm{I}_{2} \mathrm{O}_{4}$," J. Appl. Crystallogr. 20, 123-129.

Lightfoot, P., Glidewell, C., and Bruce, P. G. (1992a). "Ab initio determination of molecular structures using high-resolution powder diffraction data from a laboratory X-ray source," J. Mater. Chem. 2, 361-362.

Lightfoot, P., Hriljac, J. A., Pei, S., Zheng, Y., Mitchell, A. W., Richards, D. R., Dabrowski, B., Jorgensen, J. D., and Hinks, D. G. (1991). "BaBiO ${ }_{2.5}$, a new bismuth oxide with a layered structure," J. Solid State Chem. 92, 473-479.

Lightfoot, P., Tremayne, M., Glidewell, C., Harris, K. D. M., and Bruce, P. G. (1993). "Investigation and rationalisation of hydrogen bonding patterns in sulfonylamino compounds and related materials: Crystal structure determination of microcrystalline solids from powder X-ray diffraction data," J. Chem. Soc., Perkin Trans. 2 1993, 1625-1630.

Lightfoot, P., Tremayne, M., Harris, K. D. M., and Bruce, P. G. (1992b). "Determination of a molecular crystal structure by X-ray powder diffraction on a conventional laboratory instrument," J. Chem. Soc., Chem. Commun. 1992, 1012-1016.

Louër, D. and Louër, M. (1987). "Crystal structure of $\mathrm{Nd}(\mathrm{OH})_{2} \mathrm{NO}_{3} \cdot \mathrm{H}_{2} \mathrm{O}$ completely solved and refined from X-ray powder diffraction," J. Solid State Chem. 68, 292-299.

Louër, D., Louër, M., and Touboul, M. (1992). "Crystal structure determination of lithium diborate hydrate $\mathrm{LiB}_{2} \mathrm{O}_{3}(\mathrm{OH}) \cdot \mathrm{H}_{2} \mathrm{O}$, from X-ray powder diffraction data collected with a curved position-sensitive detector," J. Appl. Crystallogr. 25, 617-623.

Louër, M., Plevert, J., and Louër, D. (1988). "Structure of $\mathrm{KCaPO}_{4} \cdot \mathrm{H}_{2} \mathrm{O}$ from X-ray powder diffraction data," Acta Crystallogr., Sect. B: Struct. Sci. 44, 463-467.

Marinder, B.-O., Wang, P.-L., Werner, P.-E., Westdahl, M., Andresen, A. F., and Louër, D. (1987). "Powder diffraction studies of $\mathrm{Cu}_{2} \mathrm{WO}_{4}$," Acta Chem. Scand., Ser. A A41, 152-157.

Masciocchi, N., Cairati, P., Ragaini, F., and Sironi, A. (1993). "Ab initio XRPD structure determination of metal carbonyl clusters, the case of $\left[\mathrm{HgRu}(\mathrm{CO})_{4}\right]_{4}$, , Organometallics 12, 4499-4502.

McCusker, L. B. (1988). "The ab initio structure determination of sigma-2 (a new clathrasil phase) from synchrotron powder diffraction data," J. Appl. Crystallogr. 21, 305-310.

McCusker, L. B., Von Dreele, R. B., Cox, D. E., Louër, D., and Scardi, P. (1999). "Rietveld refinement guidelines," J. Appl. Crystallogr. 32, 3650.

Morris, R. E., Harrison, W. T. A., Nical, J. M., Wilkinson, A. P., and Cheetham, A. K. (1992). "Determination of complex structures by combined neutron and X-Ray-powder diffraction," Nature (London) 359, 519-512.

Morris, R. E., Owen, J. J., Stalick, J. K., and Cheetham, A. K. (1994). "Determination of complex structures from powder diffraction dataThe crystal structure of $\mathrm{La}_{3} \mathrm{Ti}_{5} \mathrm{Al}_{15} \mathrm{O}_{37}$, J. Solid State Chem. 111, 5257.

Motherwell, W. D. S., Ammon, H. L., Dunitz, J. D., Dzyabchenko, A., Erk, P., Gavezzotti, A., Hofmann, D. W. M., Leusen, F. J. J., Lommerse, J. P. M., Mooij, W. T. M., Price, S. L., Scheraga, H., Schweizer, B., Schmidt, M. U., van Eijck, B. P., Verwer, P., and Williams, D. E. (2002). "Crystal structure prediction of small organic molecules: A second blind test," Acta Crystallogr., Sect. B: Struct. Sci. 58, 647-661.

Norby, P., Christensen, A. N., Fjellvag, H., and Nielsen, M. (1991). "The crystal structure of $\mathrm{Cr}_{8} \mathrm{O}_{21}$ determined from powder diffraction data; thermal transformation and magnetic properties of a chromiumchromate-tetrachromate," J. Solid State Chem. 94, 281-293.

Pagola, S., Stephens, P. W., Bohle, D. S., Kosar, A. D., and Madsen, S. K. (2000). "The structure of malaria pigment beta-haematin," Nature (London) 404, 307-310.

Pawley, G. S. (1981). "Unit-cell refinement from powder diffraction scans," J. Appl. Crystallogr. 14, 357-361.

Pelloquin, D., Louër, M., and Louër, D. (1994). "Powder diffraction studies in the $\mathrm{YONO}_{3}-\mathrm{Y}_{2} \mathrm{O}_{3}$ system," J. Solid State Chem. 112, 182-188.

Peschar, R., Schenk, H., and Capkova, P. (1995). "Preferred-orientation correction and normalization procedure for ab initio structure determination from powder data," J. Appl. Crystallogr. 28, 127-140.

Peterson, V. K. (2005). "Lattice parameter measurement using Le Bail versus structural (Rietveld) refinement; A caution for complex, low symmetry systems," Powder Diffr. 20, 14-17.

Petit, S., Coquerel, G., Perez, G., Louër, D., and Louër, M. (1993). "Ab initio crystal structure determination of dihydrated copper(II) 5-sulfonic- 8-quinolinolato complex (form I) from X-ray powder diffraction data. Filiations with related copper(II) sulfoxinates," New J. Chem. 17, 187192.

Petit, S., Coquerel, G., Perez, G., Louër, D., and Louër, M. (1994). "Synthesis, characterization, and ab initio structure determination from powder diffraction data of a new $\mathrm{X}^{\prime}$ form of anhydrous copper(II) 8-hydroxyquinolate doped with amine. Modeling of the polymorphic transformation to the stable anhydrous beta form," Chem. Mater. 6, $116-121$.

Pivan, J. Y., Achak, O., Louër, M., and Louër, D. (1994). "The novel thiogermanate $\left[\left(\mathrm{CH}_{3}\right)_{4} \mathrm{~N}\right]_{4} \mathrm{Ge}_{4} \mathrm{~S}_{10}$ with a high cubic cell volume. Ab initio structure determination from conventional X-ray powder diffraction," Chem. Mater. 6, 827-830.

Pizarro, J. L., Villeneuve, G., Hagenmuller, P., and Le Bail, A. (1991). "Synthesis, crystal structure, and magnetic properties of $\mathrm{Co}_{3}\left(\mathrm{HPO}_{4}\right)_{2}(\mathrm{OH})_{2}$ related to the mineral lazulite," J. Solid State Chem. 92, 273-285.

Plevert, J., Louër, M., and Louër, D. (1989). "The ab initio structure determination of $\mathrm{Cd}_{3}(\mathrm{OH})_{5}\left(\mathrm{NO}_{3}\right)$ from X-ray powder diffraction data," J. Appl. Crystallogr. 22, 470-475.

Radaelli, P. G., Cox, D. E., Marezio, M., and Cheong, S. W. (1997). "Charge, orbital, and magnetic ordering in $\mathrm{La}_{0.5} \mathrm{Ca}_{0.5} \mathrm{MnO}_{3}$," Phys. Rev. B 55, 3015-3023.

Rietveld, H. M. (1969). "A profile refinement method for nuclear and magnetic structures," J. Appl. Crystallogr. 2, 65-71.

Rius, J., Sane, J., Miravitlles, C., Amigo, J. M., Reventos, M. M., and Louër, D. (1996). "Determination of crystal structures from powder diffraction data by direct methods: Extraction of integrated intensities from partially overlapping Bragg reflections," Anales de Química 92, 223-227.

Rodriguez-Carvajal, J. (1990). "FULLPROF: A program for Rietveld refinement and pattern-matching analysis," Abstracts of the meeting Powder Diffraction, Toulouse, France, pp. 127-128.

Rodriguez-Carvajal, J. (1993). "Recent advances in magnetic structure determination by neutron powder diffraction," Physica B 192, 55-69.

Roisnel, T. and Rodriguez-Carvajal, J. (2001). "WinPLOTR: A windows tool for powder diffraction pattern analysis," Mater. Sci. Forum 378381, 118-123.

Scott, H. G. (1987). PROFIT-A peak-fitting program for powder diffraction profile.

Shirley, R. (2004). "Powder Indexing," http://www.cristal.org/robin

Simmen, A., McCusker, L. B., Baerlocher, Ch., and Meier, W. M. (1991). "The structure determination and Rietveld refinement of the aluminophosphate $\mathrm{AlPO}_{4}-18$," Zeolites 11, 654-661.

Sivia, D. S. and David, W. I. F. (1994). "A Bayesian approach to extracting structure-factor amplitudes from powder diffraction data," Acta Crystallogr., Sect. A: Found. Crystallogr. 50, 703-714.

Sonneveld, E. J. and Visser, J. W. (1975). "Automatic collection of powder data from photographs," J. Appl. Crystallogr. 8, 1-7.

Stephens, P. W. (1999). "Phenomenological model of anisotropic peak broadening in powder diffraction," J. Appl. Crystallogr. 32, 281-289.

Subramanian, M. A., Toby, B. H., Ramirez, A. P., Marshall, W. J., Sleight, A. W., and Kwei, G. H. (1996). "Colossal magnetoresistance without $\mathrm{Mn}^{3+} / \mathrm{Mn}^{4+}$ double exchange in the stoichiometric pyrochlore $\mathrm{Tl}_{2} \mathrm{Mn}_{2} \mathrm{O}_{7}$, , Science 273, 81-84.

Teller, R. G., Blum, P., Kostiner, E., and Hriljac, J. A. (1992). "Determination of the structure of $(\mathrm{VO})_{3}\left(\mathrm{PO}_{4}\right)_{2} \cdot 9 \mathrm{H}_{2} \mathrm{O}$ by powder X-ray diffraction analysis," J. Solid State Chem. 97, 10-18.

Thompson, P., Cox, D. E., and Hastings, J. B. (1987). "Rietveld refinement of Debye-Scherrer synchrotron X-ray data from $\mathrm{Al}_{2} \mathrm{O}_{3}$," J. Appl. Crystallogr. 20, 79-83.

Toraya, H. (1986). "Whole-powder-pattern fitting without reference to a structural model: Application to X-ray powder diffraction data," J. Appl. Crystallogr. 19, 440-447.

Toraya, H. (1994). "Applications of whole-powder-pattern fitting technique in materials characterization," Adv. X-Ray Anal. 37, 37-47.

Tremayne, M., Lightfoot, P., Glidewell, C., Harris, K. D. M., Shankland, K., Gilmore, C. J., Bricogne, G., and Bruce, P. G. (1992a). "Application of the combined maximum entropy and likelihood method to the ab initio determination of an organic crystal structure from X-ray powder diffraction data," J. Mater. Chem. 2, 1301-1302.

Tremayne, M., Lightfoot, P., Mehta, M. A., Bruce, P. G., Harris, K. D. M., Shankland, K., Gilmore, C. J., and Bricogne, G. (1992b). "Ab initio structure determination of $\mathrm{LiCF}_{3} \mathrm{SO}_{3}$ from X-ray powder diffraction data using entropy maximisation and likelihood ranking," J. Solid State Chem. 100, 191-196. 
Von Dreele, R. B., Stephens, P. W., Smith, G. D., and Blessing, R. H. (2000). "The first protein crystal structure determined from highresolution X-ray powder diffraction data: A variant of $T_{3} R_{3}$ human insulin-zinc complex produced by grinding," Acta Crystallogr., Sect. D: Biol. Crystallogr. 56, 1549-1553.

Wessels, T., Baerlocher, Ch., McCusker, L. B., and Creyghton, E. J. (1999). "An ordered form of the extra-large-pore zeolite UTD-1: Synthesis and structure analysis from powder diffraction data," J. Am. Chem. Soc. 121, 6242-6247.

Wiles, D. B. and Young, R. A. (1981). "A new computer program for Rietveld analysis of X-ray powder diffraction patterns," J. Appl. Crystallogr. 14, 149-151.

Will, G. (1988). "Crystal structure analysis and refinement using integrated intensities from accurate profile fits," Aust. J. Phys. 41, 283-296.

Will, G. (1989). "Crystal structure analysis from powder diffraction data," Z. Kristallogr. 188, 169-186.

Will, G., Masciocchi, N., Parrish, W., and Hart, M. (1987). "Refinement of simple crystal structures from synchrotron radiation powder diffraction data,” J. Appl. Crystallogr. 20, 394-401.

Will, G., Parrish, W., and Huang, T. C. (1983). "Crystal-structure refinement by profile fitting and least-squares analysis of powder diffractometer data," J. Appl. Crystallogr. 16, 611-622.

Williams, J. H., Cockcroft, J. K., and Fitch, A. N. (1992). "Structure of the lowest temperature phase of the solid benzene-hexafluorobenzene adduct," Angew. Chem., Int. Ed. Engl. 31, 1655-1657.

Wright, J. P. (2004). "Extraction and use of correlated integrated intensities with powder diffraction data," Z. Kristallogr. 219, 791-802.

Young, R. A. (1993). The Rietveld Method (Oxford University Press, New York).

Young, R. A. and Desai, P. (1989). "Crystallite size and microstrain indicators in Rietveld refinement," Ark. Nauki o Materialach 10, 71-90.

Zah-Letho, J. J., Jouanneaux, A., Fitch, A. N., Verbaere, A., and Tournoux, M. (1992). " $\mathrm{Nb}_{3}(\mathrm{NbO})_{2}\left(\mathrm{PO}_{4}\right)_{7}$ a novel niobium $\mathrm{V}$ oxophosphate, synthesis and crystal structure determination from high resolution X-ray powder diffraction,” Eur. J. Solid State Inorg. Chem. 29, 1309-1320. 